\title{
Corporate Legitimacy as Deliberation: A Communicative Framework
}

\author{
Guido Palazzo \\ Andreas Georg Scherer
}

Modern society is challenged by a loss of efficiency in national governance systems values, and lifestyles. Corporate social responsibility (CSR) discourse builds upon a conception of organizational legitimacy that does not appropriately reflect these changes. The problems arise from the a-political role of the corporation in the concepts of cognitive and pragmatic legitimacy, which are based on compliance to national law and on relatively homogeneous and stable societal expectations on the one hand and widely accepted rhetoric assuming that all members of society benefit from capitalist production on the other. We therefore propose a fundamental shift to moral legitimacy, from an output and power oriented approach to an input related and discursive concept of legitimacy. This shift creates a new basis of legitimacy and involves organizations in processes of active justification vis-à-vis society rather than simply responding to the demands of powerful groups. We consider this a step towards the politicization of the corporation and attempt

Prof. Dr. Guido Palazzo is Assistant Professor for Business Ethics at the University of Lausanne (Switzerland). He graduated in Business Administration at the University of Bamberg (Germany) and earned his PhD in Political Philosophy (1999) from the University of Marburg (Germany). His research interests are in Corporate Social Responsibility, Corporate Branding, Democratic Theory and Organizational Ethics.

Prof. Dr. Andreas Georg Scherer is director of the Institute for Organization and Administrative Science (IOU) and holds the Chair for Foundations of Business Administration and Theories of the Firm at the University of Zurich (Switzerland). He has published six books. His work has appeared in Academy of Management Review, Advances in Strategic Management, Business Ethics Quarterly, Journal of Business Ethics,M@n@gement, Management International Review, Organization, organization Studies, and in numerous volumes and German journals. Dr. Scherer is member of the editorial boards of Business Ethics Quarterly, Organization, and Organization Studies. to re-embed the debate on corporate legitimacy into its broader context of political theory, while reflecting the recent turn from a liberal to a deliberative concept of democracy.

KEY WORDS: Business and society, business ethics, corporate social responsibility, deliberative democracy, globalization, organizational legitimacy

\section{Corporate legitimacy at stake}

Legitimacy can be understood as the conformation with social norms, values, and expectations (Oliver, 1996). It is subjectively perceived and ascribed to actions or institutions by social construction (Berger and Luckman, 1966). Legitimacy is vital for organizational survival as it is a precondition for the continuous flow of resources and the sustained support by the organization's constituents (Parsons, 1960; Pfeffer and Salancik, 1978; Weber, 1978). Persons or institutions who lose legitimacy find it difficult to enter into processes of social exchange as their partners do not rely on their compliance with social rules.

In recent years, many corporations have been involved in conflicts with civil society and as a result their legitimacy has been challenged. Financial scandals, human rights violations, environmental side-effects, collaboration with repressive regimes and other problematic issues have not only threatened the reputation of the involved firms but provoked critical questions about the societal role of business in general. Public trust in corporate morality is on the decline (Sethi, 2002) and the firm's activities are intensively scrutinized by Non-Governmental Organizations (NGOs) (Doh and Teegen, 2004; Spar and La Mure, 2003; Waddock, 2000). For NGO 
activists, multinationals' brands have become the target in the fight for decent labor, environmental and human rights standards around the world. In their eyes, companies with world-spanning networks have become the potential enemies of public interest, the distrusted actors, the "brand bullies" (Klein, 2000). Thus, legitimacy has become a very critical issue for corporations, especially for those who operate globally.

We suggest that current theorizing upon corporate social responsibility (CSR) does not adequately reflect these developments. The theoretical discourse builds mainly on the assumption of an intact regulatory environment where national legislation and the values of social communities more or less clearly prescribe appropriate business behavior. Corporations consider these rules and the expectations of powerful stakeholder groups as economic restrictions in their course towards maximizing profits. Legitimacy is thus considered as a resource to guarantee the corporation's continued existence. While even normative approaches to business ethics often do not transcend this logic we propose that under the conditions of globalization a radical reformulation of the role of legitimacy is overdue.

The paper is organized as follows. We first outline the concept of legitimacy in organization studies. We then focus on the theoretical dilemma of the current CSR debate and show how these limits arise from the a-political role of the corporation in the mainstream conceptualization of cognitive and pragmatic legitimacy. In the next section, we describe the reasons for and consequences of the proposed shift towards moral legitimacy. The focus on moral legitimacy will alter the standards of organizational legitimacy, since it involves organizations in more and more processes of active justification vis-à-vis society through communicative engagement in public deliberation. We discuss this as the politicization of the corporation. This argument is followed by our attempt to re-embed the debate on corporate legitimacy into its broader context of political theory, reflecting the recent turn from a liberal to a deliberative concept of democracy. Subsequently, the practical challenges for corporations that arise from their politicization are outlined. A reflection on some caveats concludes the paper.

\section{Managing corporate legitimacy}

Corporate legitimacy deals with the appropriate role of corporations in society. Suchman defines legitimacy as "a generalized perception or assumption that the actions of an entity are desirable, proper or appropriate within some socially constructed system of norms, values, beliefs, and definitions" (Suchman, 1995, p. 574, emphasis in the original here omitted). $\mathrm{He}$ distinguishes between three types of organizational legitimacy:

Pragmatic legitimacy results from the calculations of self-interested individuals who are part of the organization's audience, e.g., the corporation's key stakeholders or the wider public (Suchman, 1995). These individuals will ascribe legitimacy to the corporation as long as they perceive that they will benefit from the corporation's activities - e.g., through payment or cost reduction, or at least indirectly through the output of the macro economic system as a whole. Therefore, it is a key challenge for the corporation to influence individuals' calculations and to persuade key stakeholders as well as the wider public - of the usefulness of its output, procedures, structures and leadership behavior (Ashforth and Gibbs, 1990). This can be accomplished in various ways, e.g., by direct benefits to constituents, by diligent stakeholder management, by inviting stakeholders to participate in corporate decision-making, or by strategic manipulation of perceptions (e.g., through symbolic management or instrumental public relations).

Cognitive legitimacy emerges, when the societal context regards an organization and its output, procedures, structures and leader behavior as inevitable and necessary and if acceptance is based on some broadly shared taken-for-granted assumptions, i.e., when "there is little question in the minds of actors that it serves as a natural way to effect some kind of collective action" (Hannan and Carroll, 1992, p. 34). Cognitive legitimacy operates mainly at the subconscious level, making it difficult for the corporation to directly influence and manipulate perceptions strategically (Oliver, 1991; Suchman, 1995). Once a manipulation attempt is disclosed cognitive legitimacy may collapse when subconscious acceptance is substituted by explicit consideration and opposition because practices are perceived as unacceptable (see Ashforth and Gibbs, 
1990; Suddaby and Greenwood, 2005). Therefore, in many cases cognitive legitimacy can be managed only indirectly and only to a minor degree (Oliver, 1991). Rather, a firm's behavior may often result in a simple adaptation to social expectations (see, e.g., Strand, 1983).

Moral legitimacy, finally, refers to conscious moral judgments on the organization's output, procedures, structures and leaders. Moral legitimacy is socially constructed by giving and considering reasons to justify certain actions, practices, or institutions. It "reflects a prosocial logic that differs fundamentally from narrow self-interest" (Suchman, 1995, p. 579). We expect that moral concerns to some extent prove resistant to self-interested manipulations and to purely pragmatic considerations. Suchman describes the moral legitimacy of organizations as the result of "explicit public discussion" and in his view corporations can win moral legitimacy only through their vigorous participation in these discussions (Suchman, 1995 , p. 585). The management of moral legitimacy, therefore, must be conceived of as deliberative communication: Rather than manipulating and persuading opponents the challenge is to convince others by reasonable arguments.

An organization is perceived as legitimate, if it pursues "socially acceptable goals in a socially acceptable manner" (Ashforth and Gibbs, 1990, p. 177). In CSR research, ${ }^{1}$ a broad range of theories is dealing with the concrete meaning of this rather abstract demand. The role of corporations in society is discussed under different headlines with the notions of "corporate social responsibility" (CSR), "corporate citizenship" (CC), "corporate sustainability", "business ethics", or "stakeholder theory" dominating the debate. Despite the fact that there is no terminological consistency, the core assumption of all these concepts - sometimes defined in a more instrumental line of argument, or in a more categorical way - is the unavoidability of normative conformity with the social environment (e.g., Carroll, 1979, 1998; Maignan and Ferrell, 2000; Strand, 1983; Wartick and Cochran, 1985; Wood, 1991). Legitimacy, therefore, is the "yardstick" of the discussion in the CSR field (Sethi, 1975, p. 60).

Kostova and Zaheer (1999) suggest three factors influencing corporate legitimacy: (a) the characteristics of the societal environment that lead to a specific set of demands vis-à-vis a corporation, (b) the characteristics of the organization that manifest in a specific perception by the societal environment and (c) the process by which legitimacy is produced, in particular, how the corporation manages legitimacy (Suchman, 1995). If corporate legitimacy is based upon the characteristics of the societal environment it can be assumed that deep environmental changes have a significant influence on the social expectancies towards organizations, which again may lead to alterations in corporate behavior ("corporate social response", see Strand, 1983). Furthermore, if the conditions of social acceptance change, the perception of the legitimacy of a particular form of organization, e.g., corporations, or type of behavior, e.g., unconditional profit seeking, may also change (see, e.g., Suddaby and Greenwood, 2005). As a consequence, this may have an impact on the process by which legitimacy is produced and the suitability of different strategies of "managing legitimacy".

Our paper demonstrates that modern society is indeed subject to significant change. We will discuss these changes as the transition from stable industrial society to postindustrial and postnational society (Habermas, 2001) and suggest that business firms today must reconsider their policies to maintain and reproduce legitimacy. We will argue that the two dominating approaches of cognitive and pragmatic legitimacy do no longer suffice for protecting the corporate licence to operate. More and more situations call for these approaches to be complemented by moral access to corporate legitimacy.

Suchman (1995) proposes two main approaches to "managing legitimacy" - strategic and institutional. According to the institutional approach, organizational legitimacy results from the organization's cultural embeddedness that is displayed in its compliance with generally accepted norms, values and beliefs in society (DiMaggio and Powell, 1983; Dowling and Pfeffer, 1975; Oliver, 1996). The institutional approach describes organizational legitimacy as a continuous and often unconscious adaptation process in which the organization reacts to external expectations. Therefore, with the institutional approach, the potential to really "manage" legitimacy is limited (Suchman, 1995) and only under certain conditions can organizations resist adaptation (see, e.g., Oliver, 1991; Zald et al., 2005, p. 264 ff.). 
By contrast, the strategic approach treats legitimacy as an "operational resource" (Suchman, 1995) that can be managed and directly influenced by the corporation (Ashforth and Gibbs, 1990). Seen from this perspective, legitimacy is based on the corporation's ability to "instrumentally manipulate and deploy evocative symbols in order to garner societal support" (Suchman, 1995, p. 572). These strategic efforts, however, often remain merely a symbolic reaction to legitimacy pressures. Such organizations deem it as important simply to appear consistent with normative demands from their societal context. They attempt to build symbolic links with other values, symbols or persons that are highly respected in order to create some reputational endorsement effects (Ashforth and Gibbs, 1990; Fombrun, 2001).

The successful management of organizational legitimacy by both, passive compliance and active manipulation, contributes to corporate survival. Corporations are then perceived as meaningful, predictable, and trustworthy and audiences are more likely to supply resources to legitimate organizations (Suchman, 1995). By contrast, organizations with fragile legitimacy run the risk of being perceived as unnecessary or irrational (Meyer and Rowan, 1977). They are less stable and persistent (Suchman, 1995).

We suggest that the current debate on a corporation's societal responsibilities is built upon a discussion of organizational legitimacy that does not appropriately reflect the conditions of a postnational and pluralistic society. The strategic approach on the one hand is overly focused on pragmatic legitimacy, assuming that corporations have the power to strategically influence their societal context thus manipulating the process of legitimacy ascriptions. Following Suchman (1995), strategic manipulation does not help in ensuring moral legitimacy or, at least due to its short term effects, does not help to stabilize it. The institutional approach on the other hand takes cognitive legitimacy as its mainstream point of reference. In our context, cognitive legitimacy is based upon the idea of a nationally bound society with a national governance system and a dense and homogeneous cultural background of shared norms, values and beliefs (Suchman, 1995). However, as we are going to demonstrate, the pluralization of modern society (understood as the threefold process of individualization, the devaluation of tradition, and the globalization of society) results in a loss of cultural homogeneity and erodes the normative taken-forgrantedness as it is assumed in the concept of cognitive legitimacy. If we follow Suchman's thesis that pragmatic legitimacy is too weak due to its limited (group-specific) and ephemeral impact and if we further assume that cognitive legitimacy is devaluated through pluralization, moral legitimacy becomes the decisive source of societal acceptance for corporations in an increasing number of situations.

\section{The theoretical dilemma of a thin concept of corporate legitimacy}

The main focus of the CSR debate is on instrumental interpretations of corporate responsibility (see, e.g., Jones, 1995) and thus on pragmatic or cognitive conceptions of legitimacy. The key argument is that in capitalist societies business firms must earn profits (Sundaram and Inkpen, 2004). Therefore, in the long run, this objective is best served by adopting a strategic approach towards CSR, i.e., rational managers of business firms invest in CSR initiatives as long as they earn extra profits (see, e.g., McWilliams and Siegel, 2001). This is also implicitly assumed within many empirical studies on corporate social performance - corporate financial performance relationship (see, e.g., Orlitzky et al., 2003). However, this strong dominance of instrumental interpretations of CSR has come under pressure for its theoretical limits (Matten and Crane, 2005). If CSR is merely justified by a - more or less empirically validated - potential to increase long-term profits, the neoclassical rhetoric remains salient (see critically, Dubbink, 2004; Margolis and Walsh, 2003; Ulrich, 2002; Vogel, 2005).

In order to transcend this narrow focus, there has been a call for a more interdisciplinary approach to organization studies with a more prominent role for the humanities (Wicks and Freeman, 1998) and political theory (Dubbink, 2004; Matten and Crane, 2005). The aim is to re-embed economy in its overall ethico-political context (Ulrich, 2002). It has been argued that the link between business and society is "inherently normative, because it seeks to explain what corporations should or should not do on behalf of the social good" (Swanson, 1999, p. 506).

There have been fruitful attempts to go beyond a purely instrumental conceptualization of corporate 
responsibility and to place it in a broader ethical context such as fundamental rights (Donaldson and Preston, 1995) or the intrinsic worth of human beings (Donaldson and Dunfee, 1999; Freeman, 2002). In a recent contribution, an important step was taken placing the debate on CSR into the broader discourse of political theory. Matten and Crane (2005) reinterpret the notion of corporate citizenship (CC) based on its terminological use in political theory. In their conceptualization of CC they refer to the three dimensions of civic rights (social, civil and political) and interpret the corporation's role as one of enabling, providing and channeling these rights for citizens in situations where the state is either unwilling or uncapable to protect them. Both authors concede, though, that their conceptualization remains merely descriptive in the sense that it outlines the current practice of corporate engagement rather than deriving the normative consequences of the emerging changes in societal governance structures (Matten and Crane, 2005; see, critically, Oosterhout, 2005). However, their politicized concept of CC is not yet integrated into the more or less depoliticized discussion on CSR and its limited concept of corporate legitimacy.

The theoretical narrowness and missing rigor of the CSR debate can be traced back to the fact that it mainly rests upon cognitive and pragmatic concepts of corporate legitimacy and that it is not sufficiently linked to the overarching debate on the (moral) legitimacy of political institutions and processes (see Habermas, 1996). The self-reference of organizational legitimacy theory separates it from an appropriate analysis of societal changes. As we will argue, this theoretical separation is based upon the historically developed de-politicization of the corporation. By political we mean activities "in which people organize collectively to regulate or transform some aspects of their shared social conditions, along with the communicative activities in which they try to persuade one another to join such collective actions or decide what direction they wish to take" (Young, 2004, p. 377).

The liberal idea of maintaining legitimacy of political institutions and processes is linked to the historically grown differentiation between the state and society. Civic liberties have been developed as a protection from the arbitrary use of power by absolutist rulers. In medieval Europe, civic liberties originally emerged as the relative freedom of towns and their respective citizens from the influence of feudal structures (see, e.g., Skinner, 1989). During the Renaissance in Italy some towns established these liberties and thus managed to contribute to the modest independence of their citizens. However, liberty was first understood as economic liberty, i.e., as the freedom of economic choice and protection from the ruler's interferences. Accordingly, citizen rights originally began as property rights and contractual rights (MacPherson, 1962) and only over time were these rights complemented by political rights (i.e., participation in public will formation) and social rights (i.e., right to education, health care, welfare etc.) (Marshall, 1965).

In modern liberal society citizens enjoy a private sphere of voluntary cooperation and exchange with their fellow citizens, a sphere free of arbitrary intervention by public institutions or third parties. As a consequence, in its most radical form, modern liberalism regards civil protection against arbitrary coercion by public authorities or by fellow citizens as the only common aim of individuals in a free society (Hayek, 1960; Manin, 1987). Any step towards a stricter regulation of private activity or expansion of public authority is therefore suspect. Though some additional state activities are considered necessary preconditions of social integration (e.g., education, monetary system, supply of public goods etc.) (Friedman, 1962) the scope and intensity of state activities has remained a highly controversial issue (e.g., Block, 1994). The state apparatus has to be controlled by democratic election and binding rules so that the definition of public authority or the execution of state power can be restricted to politically legitimate actions and institutions that are in the interest of all citizens. Thus, in the democratic constitutional state public authority is bound by the rule of law and the free will of the people. ${ }^{2}$ Legal rules and public policies derive their legitimacy from the reason and will of the citizens whose decisions and actions are supposed to be limited or affected by them (Habermas, 1996). By contrast, the activities of private actors, and corporations as the economic extension of the private self, are not subjected to immediate legitimacy demands, i.e., demands that go beyond legal requirements and rules of common decency (Friedman, 1962). As a result, the activities of economic actors have been depoliticized (see also 
Scherer and Palazzo, forthcoming; Scherer et al., forthcoming):

The emphasis in economic theory on freedom of choice in the market sphere suggests that legitimization in the market sphere is "automatic" and that markets thus avoid the typical legitimization problem of the state (Peters, 2004, p. 1).

Therefore, in the dominating liberal concepts of political theory, corporations are rather subjects of legitimacy demands than objects to it. Within this approach there is no additional obligation for publicly justifying private economic activities beyond the simple compliance with the basic legal and moral rules of the surrounding society. Friedman's (1970) famous description of profit as the only social responsibility of a corporation is a modern reflection of these deeply ingrained overarching concepts of liberal political legitimacy.

However, in capitalist societies the role of business as a value creating (albeit not always maximizing) institution is more or less taken for granted. Corporate legitimacy thus mainly rests on a cognitive conception of legitimacy as long as there is "little question in the mind of actors" that the business firm "serves as a natural way" of how modern society works (see, Hannan and Carroll, 1992, p. 34). And even when this assumption is contested economists hurry to maintain the capitalist rhetoric. By stating that "200 year's worth of work in economics and finance indicate that social welfare is maximized when all firms in an economy maximize total firm value" Jensen (2002, p. 239) wants to sustain the perception that society will benefit from the capitalist institution of the business firm run by selfish entrepreneurs. ${ }^{3} \mathrm{He}$ thus points to the pragmatic legitimacy of the corporation. Within this rhetoric there seems to be no need for an additional responsibility of the business firm beyond legal requirements and the economic interests of the firm. Therefore, it has always been regarded as unavoidable to deliver an economically convincing answer to issues of CSR (see, e.g., McWilliams and Siegel, 2001). Paradoxically, with their focus on the utility value of responsibility, even authors who appeal for a broader view on CSR often do not transcend that limited conceptual framework (see, critically, Margolis and Walsh,
2003; Vogel, 2005). Donaldson and Preston point at the irony of the stakeholder model being justified within the analytical framework of economic theory (Donaldson and Preston, 1995).

There seems to be no reliable basis for a broader understanding of corporate legitimacy for one basic reason. The liberal and neoclassic understanding of corporations as the extension of the private self leaves no room for a genuine ethico-political interpretation of corporate behavior. The traditional division of labor between business and government as it has been established during stable industrial society manifests in Levitt's argument that the role of business is to make a profit and that social responsibility is the task of government (Levitt, 1970; for a more recent expression of this argument see Sundaram and Inkpen, 2004). This strict and deeply engrained separation of economic and political responsibilities explains the harsh critique against CSR as it has been formulated by economists (see, e.g., Economist, 2005; Friedman, 1962; Henderson, 2001; Jensen, 2002; Lal, 2003). Reich (1998, p. 17) concludes that too much corporate interference in non-business activities that are normally under the responsibility of the state probably leads to a weakening of the political system and to a problematic "politicization of the corporation". However, in our view, the politicization of the corporation is an unavoidable result of the changing interplay of economy, government and civil society in a globalizing world (Scherer and Palazzo, forthcoming; Scherer et al., forthcoming). These societal changes cast doubt upon the validity of the established interpretation of the corporation as an extension of the private self. Current concepts of organizational legitimacy that refer either to a weak idea of a corporation's cognitive compliance or to the pragmatic legitimacy provided by capitalist rhetoric will come under pressure. In the following chapter, we describe the shift from the industrial to the postindustrial and postnational society and derive some consequences for a politicized concept of organizational legitimacy.

\section{The politicization of the corporation}

De-politicized corporate legitimacy in its mainstream understanding is based on the containment 
logic of the nation state with its limited geographic expansion and distinctive normative tradition (Kobrin, 2001). To use the differentiation as developed by Suchman, corporate legitimacy is strongly linked to the taken-for-grantedness of a cognitive access to legitimacy. This becomes obvious considering the arguments proposed in the debate on CSR from a wide range of perspectives (see, critically, Scherer and Palazzo, forthcoming). Carroll (1979, p. 500) suggests that corporations' responsibilities derive from societal expectations "at a given point in time", while Swanson (1999, p. 517) holds that corporations have to align their activities with "broader community values". Epstein and Votaw (1978, p. 3) argue that corporations must act consistently "with the moral foundations of ... society", and even Friedman (1970, p. 218) concludes that corporations have to conform "to the basic rules of the society, both that embodied in law and those embodied in ethical custom". Accordingly, current conceptualizations of CSR assume that legitimacy is based on conformity with societal rules. This assumption has become very problematic because of the massive expansion of corporate activities into different countries and cultures. On the global level the idea of conformity to some more or less implicit rules of some more or less contained social communities is difficult to comprehend. On the global playing field, there are no broadly accepted normative standards, neither in legal, nor in moral terms (Habermas, 2001; Huntington, 1998).

As a consequence, legitimacy has become one of the most critical business issues, especially for those companies that operate globally. Kostova and Zaheer $(1999$, p. 74$)$ demonstrate that the power of multinationals may result in economic advantages but turns into a "source of vulnerability in non-market activities such as the maintenance of legitimacy". In a globalized world, multinationals face a much higher level of complexity compared with the more homogeneous national context of the pre-globalization age (Kostova and Zaheer, 1999; Meyer and Scott, 1983). On the global level the legitimacyascribing environment is not very homogeneous. Rather one can observe a multiplicity of contradictory legal and moral requirements (e.g., Kobrin, 2001; Young, 2004). Therefore, it is difficult to identify which of these demands will define the legitimacy of organizational behavior. Oliver (1991) suggests that the greater the multiplicity of constituent expectation is the higher the likelihood of organizational resistance towards these expectations. She holds that under these conditions corporations may not respond with adaptation but with strategies of compromise, avoidance, defiance, or even manipulation in order to maintain legitimacy.

The growing complexity of globalized social networks is accompanied by an internal pluralization of postindustrial societies. These are characterized by an ongoing process of individualization where the once more or less homogeneous cultural life-world background becomes fragmented. Values, interests, goals and lifestyles are pluralizing and societies struggle with growing complexity and heterogeneity (BeckGernsheim and Beck, 2002). The consequence for discussions on legitimacy is quite obvious: Historical transitions provoke legitimacy frictions (Suchman, 1995). Conclusively, Habermas (1996, p. 97) holds: "One no longer legitimates maxims, practices, and rules of action simply by calling attention to the contexts in which they were handed down".

Therefore, the taken-for-grantedness of a corporation's societal background that was initially the main source for cognitive legitimacy evaporates. But at the same time legitimacy issues become more salient - a phenomenon that can be explained by the dynamics of globalization. Globalization does not only macerate the cultural background of the nation state, it furthermore leads to a vivid debate on the interplay of state, economy and civil society (see, e.g., Beck, 2000; Kobrin, 2001), which in turn results in re-conceptualizations of legitimacy in political theory (e.g., Nanz and Steffek, 2004).

In recent years, it has been maintained that the main threats to civic liberties no longer come from state authorities but from private economic actors (Beck, 1992; Deetz, 1995; Ulrich, 1993). Corporations have become "quasi-public" actors beyond what Berle and Means had in mind when they described the public character of corporations as the result of stock company growth (cf. Berle and Means, 1932, p. 333). Today, companies are quasipublic actors because of the politicization of their activities through unintended side-effects and the lack of global regulation. Especially for transnationally active corporations it has been argued that they link private decisions with problematic collective effects and bindings (Beck, 1992; Klein, 2000; 
Scherer, 2003; Ulrich, 1993). Private activities that originally were considered politically neutral are now loaded with more and more public demands. Transnational corporations are morally scrutinized along their supply chain, whether or not the criticized activity is executed by the corporation itself or by a legally independent supplier. Young (2003, 2004) emphasizes that the claim of responsibility as it has been put on the agenda by the anti-sweatshop movement is quite novel in the sense that it "involves an argument that agents are responsible for injustice by virtue of their structural connection to it, even though they are not to blame for it" (Young, 2003, p. 40). This argument holds true for a diverse set of human rights issues (e.g., slave labor, child labor, forced labor, general working conditions, environmental pollution, and collaboration with repressive regimes).

In a world society without a world state there is an emerging need to "re-set the standards by which we assess legitimacy" (Zürn, 2000, p. 190). Political theory has only just discovered the corporation as a political actor. Issues are defined as political if they provoke public concern resulting from power. Power in principle requires legitimacy (cf. Steffek, 2003; Weber, 1978, p. 213). Corporations have become "the most important new political institution in the contemporary political order" (Mitchel, 1986, p. 208). The growing public influence of corporations raises questions about the public impact of private authority on national sovereignty and democratic governance (Habermas, 2001; Kobrin, 2001; Rondinelli, 2002; Wolf, 2005). Multinational corporations have developed an economic, social, and political power that is comparable to the power of nation states, as Epstein already noted in 1972 (Epstein, 1972). The debate on social responsibility seems to be the result of a process of discussing future rights and obligations of corporations in the democratic order. Therefore, the purpose of the firm and its place in society has to be redefined (Scherer, 2003; Walsh et al., 2003).

To ascribe a political role to corporations is not only an abstract theoretical endeavor. Rather, it has already gained practical importance by the reality of corporate political engagement apparent today. Corporations, especially transnational corporations, already assume political responsibilities that once where genuine governmental responsibilities: they protect human rights or define and enforce social and environmental minimum standards, they address social misery such as AIDS, malnutrition, homelessness or illiteracy (Margolis and Walsh, 2003) and engage in public health, education or social security (Matten and Crane, 2005). Today, corporations assume an ever expanding set of social responsibilities including more and more activities that formerly were regarded as activities of the political system (see, e.g., Harman and Porter, 1997). In such contexts, the clear division of labor between the political and business actors as it is included in both, the pragmatic and the cognitive concept of legitimacy becomes highly disputable.

\section{Corporate legitimacy in a globalized world: towards a communicative approach}

In their recent paper, Matten and Crane (2005) mention as one of the potential normative consequences of their politicized approach to a corporation's civic responsibility that corporate behavior should probably be submitted to stricter democratic accountability. We take up that assumption and propose a discursive interpretation of CSR focusing on the important role of civic engagement and civic interaction for processes of legitimacy. The call for discourse and communicative ethics in the broad field of corporate responsibility studies (e.g., Suchman, 1995; Swanson, 1999; Wicks and Freeman, 1998) denotes a politicization of the corporation since it opens corporate decision-making to civil society discourses.

Our thesis is that in the current transition from stable industrial society to a globalized postindustrial society, cognitive legitimacy is eroding (e.g., shareholder-value ideology, free and open market narratives, normative homogeneity) while pragmatic legitimacy (e.g., lobbyism, branding, strategic public relations) provokes growing resistance (e.g., antiglobalization movement, no logo movement). Therefore, moral legitimacy has become the core source of societal acceptance. Johnson and Holub (2003) deliver an example for that thesis. After September 11, 2001 the habit of moving to offshore havens to lessen tax burdens was considered unpatriotic. Previously accepted business behavior suddenly became subject to critical public debate (for a 
critical discussion see, e.g., Palan, 2003). This clearly shows, how established business practices can lose their cognitive legitimacy very rapidly and instead become highly politicized.

Moral legitimacy cannot be engineered, manipulated or bought by organizations (Suchman, 1995), even if it is quite a habitual approach of companies for react to all kinds of legitimacy pressures by strategically adopting "certain highly visible and salient practices that are consistent with social expectations while leaving the essential machinery of the organization intact" (Ashforth and Gibbs, 1990, p. 181). These strategic efforts may secure the support of some stakeholders for a while, but will definitely not lead to moral legitimacy. On the contrary, the attempt to engineer moral legitimacy, through symbolic or strategic activities, such as instrumental public relations or political lobbying (see, e.g., Hillman et al., 2004; Keim, 2001; Shell, 2004), may even increase moral indignation and further reduce public acceptance (Ashforth and Gibbs, 1990).

While theories of organizational legitimacy normally refer to the compliance with some taken-forgranted societal background rules, we argue that the idea of public acceptance can no longer be decoupled from public discourse. Instead, moral legitimacy results from communication (Suchman, 1995). Today, complying with the normative standards of society has less to do with the habitualization of existing norms or the engineering of corporate image than with participating in public discourse and providing good reasons and accepting better reasons. The key questions, theories of organizational legitimacy have to answer, are the following:

1. If alignment with "broader community values" (Swanson, 1999, p. 517) is the core issue for corporate legitimacy, how can it be established in a normative context that becomes transnationalized, fragmented, pluralized, more complex and less understandable (see, e.g., Kostava and Zaheer, 1999)?

2. How can corporations identify the normative standards of their societal environment and what are they expected to do if these standards collide (see, e.g., Oliver, 1991)?

We suggest that against the background of nonexistent or insufficient institutions on the global playing field, discourses offer an important contribution to processes of problem-solving (Steffek, 2003). Dryzek comes to a similar conclusion $(1999$, p. 35):

Discourses are intertwined with institutions; if formal rules constitute institutional hardware, then discourses constitute institutional software. In the international system, the hardware is not well developed, which means that the software becomes more important still.

A turn towards moral legitimacy, as it is suggested here, implicates a turn from the economic, utilitydriven, and output-oriented view on CSR to a political, communication-driven, and input oriented concept of organizational responsibility. The priority of the political is expressed in a strong link between corporate decision-making and processes of willformation in a corporation's stakeholder network (Wicks and Freeman, 1998; Young, 2003). According to Swanson, a communicative approach to moral conflicts could offer conceptual background for the exchange of value-based information between a corporation and its societal environment (Swanson, 1999). In a similar vein, Calton and Payne deliver a communicative definition of a stakeholder network, describing it as "an interactive field of discourse" (Calton and Payne, 2003) which they place in the context of the emerging view of organizations as interconnected conversations (e.g., Calton and Kurland, 1996; Deetz, 1995; Kuhn and Ashcraft, 2003; Wicks and Freeman, 1998).

If normative conflicts can no longer be solved by referring to a shared background of values and traditions, communication becomes the sole source of peaceful interaction and mutual recognition (cf. Habermas, 2001, p. 74). This is especially true in a context of non-existing or weak global governance mechanisms. We therefore propose to embed organizational legitimacy theory and derived discussions on CSR in a communication-based approach to political theory. What will such an approach look like?

\section{Communicative legitimacy in the theory of deliberative democracy}

Modern theories of political legitimacy link the rightfulness of domination to the consent of the 
governed citizens. According to Max Weber, legitimacy describes a social order that disposes of "the prestige of being considered binding" (Weber, 1978, p. 31). The binding character of a social order is based upon its capacity to produce "rationally debatable reasons" (Weber, 1978, p. 979). From a pragmatic perspective organizational legitimacy is mainly reconstructed following utilitarian rationality (Suchman, 1995). We describe the interpretation of civic rights as property rights as one explanation for this phenomenon. A second explanation might come from the fact that in the overarching discourse on political theory itself, the same output-oriented conceptualization of legitimacy has dominated the debate for decades (Dahl, 1967; Easton, 1969; Epstein, 1972; Hurst, 1970). In liberal theory, the binding character of a democratic social order is explained by its institutional efficiency. Democracy is understood as a system of election, vote-aggregation, and representation and civic interaction is conceived as market-structured (cf. Elster, 1986; Habermas, 1998b, p. 239). The citizens have to be unburdened from political engagement and the state is organized in a Schumpeterian political system of competitive elitism. From a liberal point of view, the political role of the citizen is reduced to the decision act at the polls where electorates express their preferences while the process of developing and changing these preferences is neglected (see, Elster, 1986). Therefore, legitimacy in this case is less based on civic self-determination and more on the utility value of the political system (cf. Habermas, 1998b, p. 248).

However, in recent years, liberal concepts of vote-aggregation and bargaining have come under the pressure of societal pluralization. Pluralization, understood as the threefold process of individualization, the devaluation of tradition and the globalization of society as it was explained above, results in a loss of traditional certainties. The fragmentation of cultural homogeneity provokes "the intrusion of reflection into life histories and cultural traditions" (Habermas, 1996, p. 97) thereby leading to a growing awareness of civic autonomy and selfdetermination. A linguistic turn in contemporary political philosophy has been regarded as an unavoidable consequence of pluralization (Dryzek, 2001) and is discussed in the deliberative approach to political theory:
The conception of deliberative democracy ... puts moral reasoning and moral disagreement back at the center of everyday politics. It reinforces and refines the practice of moral argument that prevails in ordinary political life - the way in which citizens deal with moral disagreement in middle democracy. Its principles show citizens and their representatives how to live with moral disagreement in a morally constructive way (Gutmann and Thompson, 1996, p. 661).

The concept of deliberative democracy covers "any one of a family of views according to which the public deliberation of free and equal citizens is the core of legitimate political decision-making and selfgovernment" (Bohman, 1998, p. 401). Where liberal theory is focused on the output of democracy (societal welfare), deliberative democracy is focusing on the input (civic participation). Accordingly, legitimacy is regarded as the result of a process of public deliberation (Dryzek, 2001; Manin, 1987; Steffek, 2003). It is based on an "interactive rationality" (Benhabib, 1993, p. 6) that may lead to "a free and reasoned agreement among equals" (Cohen, 1989, p. 22). Collective outcomes of deliberation derive their legitimacy from the degree to which they reflect the plurality of competing discourses in the public sphere (Dryzek, 2001). In contrast to liberal processes of bargaining, where only threats and incentives lead to interest-aggregation of strategic actors, deliberation is at least partly based on common goals, values and goodwill (Zürn, 2000). Deliberation is a process through which participants address their conflicts, share information, exchange arguments and make decisions. In the arena of political deliberation, opposing positions are weighed by exchanging good reasons (Manin, 1987). Deliberation presupposes the willingness to expose one's position to validity claims and the motivation to strive for mutual understanding (see Habermas, 1990, pp. 44 and 58; 1993, p. 56). In contrast to bargaining, participants are ready to change their opinions during discourse (Manin, 1987). As a precondition, deliberation includes a concern for the well-being of the whole and that sense of community is reinforced by the process of deliberation itself (Zürn, 2000). Processes of deliberation lead to better and broader accepted political 
decisions and a deeper mutual understanding of the involved stakeholders and thus contribute to sustaining moral legitimacy. These positive effects can even be expected under suboptimal discourse conditions (Fung, 2005).

In the concept of deliberative democracy, legitimacy is based on the institutional design of discursive arenas and the procedural design of public will-formation (Dryzek, 1999, p. 43; Habermas, 1996). Accordingly, a vivid public sphere is a core aspect of deliberative democracy. The public sphere can be regarded as a communicative network in which positions are synthesized into "bundles of topically specified public opinions", echoing the problems of citizens (Habermas, 1996, p. 360). The linguistic construction of the public sphere is achieved by more or less spontaneously emerging movements and civil society associations that map, filter, amplify, bundle and transmit private problems, values and needs (see Habermas, 1996, p. 367).

The discussion on deliberative democracy is fueled by the rising significance of civil society actors (see, e.g., Boli and Thomas, 1999; Keck and Sikkink, 1998; Smith et al., 1997) and the growth in NGOs' activities (Wulfson, 2001). Nanz and Steffek (2004) suggest that the shrinking power of the political system is - at least partly - compensated by a politicization of civil society itself. This phenomenon has also been described as a "globalization from below" (Beck, 2000, p. 68). Civic political emancipation does not only affect the dynamic between civil society and the state. Under the "postnational condition" (Habermas, 2001), even the link between civil society and the economy is politicized. Where states lose their power, NGOs start to deal directly with the new owners of power, the corporations. Many observers point to the increasing visibility of anti-corporate activities and emphasize the growing importance and influence of individual and collective civil society actors (Hertz, 2001; Spar and La Mure, 2003; Tapscott and Ticoll, 2003). These initiatives result in a direct pressure of civil society activists on economic actors and have been described as "paragovernmental activities" (Dryzek, 1999, p. 44). Apparently, the rising power of corporations and the comparable powerful reactions by civil society actors lead to a changing dynamic between state, economy, and civil society groups (Kobrin, 2001). The traditional institutional order as established during stable industrial society experiencing dramatic changes. Significant alterations in global politics result in de-centering state authority and increasing political power of originally nonpolitical and non-state actors such as transnational corporations, NGOs, and intergovernmental organizations (Kobrin, 2001; Maragia, 2002). As a consequence, legitimacy in a transnational context has to be considered with regard to the emerging governance institutions and procedures beyond or above the nation state (Steffek, 2003; Wolf, 2005). Therefore, business firms have to satisfy larger demands for justifying their legitimacy.

Actors from the economic systems are immediately confronted with moral legitimacy claims, whereas during stable industrial society these claims are, as described, more or less hidden in implicit consensus on traditional customs and values (cognitive legitimacy) or the more or less accepted capitalist rhetoric of corporate economic activities contributing to the public good (pragmatic legitimacy). Today, citizens look deeply into the operations of a company and they enforce transparency and accountability where it is not delivered on a voluntary basis (Tapscott and Ticoll, 2003). NGOs become the mediating forces between the market and morality (Dubbink, 2004). In a deliberative concept of democracy as outlined here, the moral context of corporate activities is no longer based on societal rules which are taken-for-granted, but rather on the public discourses of civil society. And the more active citizens in their different stakeholder roles become, the greater the need to deal with their demands in a discursive way. Stating this we are able to conceptualize the process by which corporate moral legitimacy must be reproduced: by placing corporations into public communication network.

A discursive approach to organizational legitimacy leads to a politicized concept of CSR. Unlike the strategic approach to instrumental politics, which attempts to manipulate the system of political governance (see, e.g., Hillman et al., 2004; Keim, 2001) and which may eventually lead to pragmatic legitimacy, the deliberative politics approach goes beyond narrow self-interested manipulations and purely pragmatic considerations (Suchman, 1995). The challenge of communicative access to legitimacy is to engage in true dialogue, to convince others of the validity of one's arguments but not to persuade or 
manipulate by means of strategic instrumentalization. However, at the same time the communicative approach does not aim at overburdening the corporation with political demands. Friedman (1962, 1970) feared that normative demands beyond profit making would overburden the economic actors and lead to a too densely regulated system of corporate control. As a result, efficiency would be reduced and individual freedom which mainly manifests in property rights would be endangered. However, in a postindustrial and postnational world in which unintended side-effects become a more serious threat to the individual freedom of the affected and in which the taken-for-granted context of normative control is eroding, the two main pillars of the neoclassical shareholder-ideology collapse.

However, to regard the corporation as a political player whose legitimacy is based on civil society discourses does not mean that corporations should completely transcend the economic logic. Their viability still depends on their ability to make a profit (Steinmann and Scherer, 2000). We argue that the societal limits to profit making have shifted from simply complying to nation state regulations and adhering to a more or less implicit set of coherent societal expectations as it was envisioned by Friedman $(1962,1970)$ to a more complex communicative process of accountability where these limits are defined and redefined in a continuous process of deliberative discourse. This shift also signifies the necessary transition from a cognitive and pragmatic approach to a moral approach in more and more legitimacy challenges of corporate decision-making.

A deliberative concept of organizational legitimacy would, however, acknowledge the priority of systemic routine. This means that we still consider market transactions as the primary mode of coordination in the globalized society of anonymous individuals. However, in order to domesticate market forces even in light of the shrinking power of nation state governance and the loss of the implicit consensus of shared cultural rules and values we need new forms of governance to establish a new legitimate political order that goes beyond the traditional forms of democratic nation state regulation (Scherer and Palazzo, 2005; Scherer et al., forthcoming; Wolf, 2005). The concept of deliberative discourse is an attempt to draw the outline of such a new form of governance acknowledging the contributions that could be made by public and by private actors. The responsibility of civil society is, e.g., to question, to criticize and to publicize whenever the consequences of market behavior appear to be problematic (Dryzek, 1999; Steinmann and Scherer, 2000). As these remarks may indicate, it is not our intent to develop an entirely different, revolutionary concept of societal integration: "Communicative power is exercised in the manner of a siege ... without intending to conquer the system itself' (Habermas, 1996 , p. 486 et seq.; for a rigorous critique of this premise see Noonan, 2005). Despite the day-to-day priority of economic routine, corporations must remain open to critical deliberation in principle their primary source of societal acceptance:

The issue of legitimacy does not arise unless an order is contested. An order is contested when, for instance, new practice emerges, new rules are promulgated, or new actors rise and demand participation in a system that traditionally kept them outside (Maragia, 2002, p. 312).

\section{Conclusion}

Management theory has paid too little attention to the relationship between business and society (Walsh et al., 2003) or interpreted that relationship in a purely economic way (Perrow, 2000; Vogel, 2005). The present paper is an attempt to contribute to the discussion on CSR with an alternative approach, i.e., a discursive reinterpretation of organizational legitimacy. However, our political conception of the relationship between business and society is not without problems. We conclude our paper by outlining three potential caveats: non-discursive activism, dissensual communication, and media effects.

\section{Non-discursive activism}

Civil society activism is not always based on or aiming at public deliberation. Civil society activists use a broad range of non-discursive strategies in order to influence corporate behavior. Hill and Jones (1992) distinguish between legalistic approaches (e.g., NGOs file lawsuits against exit strategies (e.g., NGOs promote boycotts of a corporation's products), and voice strategies (NGOs 
try to stimulate awareness, e.g., through demonstrations in front of corporate facilities or street marches). Activists often refuse to participate in civil society discourses, because they fear the overwhelming influence of existing structural inequalities such as the power of a corporation on the outcome of such a discourse (Young, 2001). We concede that non-communicative strategies of resistance are sometimes necessary for creating public awareness and corporate willingness to participate in public debates (Oliver, 1991). The fact that human rights conditions in the sweatshops of the apparel industry are highly ranked on the agenda of civil society discourse is the result of initial pressure, not of deliberation (see, e.g., Zadek, 2004). But pressure is as inappropriate as corporate lobbyism in the production of solutions based on moral legitimacy. In our paper, we analyzed and criticized non-discursive strategies and communications of corporations. However, it remains necessary, to critically analyze the role and behavior of non-discursive activism in the arena of public will-formation, too (see, e.g., Spar and La Mure, 2003).

\section{Dissensual communication}

Conflicts between corporations and their societal environment are more and more based on identity and values instead of interests (Rowley and Moldoveanu, 2003). As a consequence, shared solutions in the form of a consensus or even a compromise become quite improbable (see McCarthy, 1996). Activists who fight against abortion, genetically modified food, or child labor would regard any compromise with the targeted corporation as a threat to their personal integrity, as a betrayal of "some... deeply held ethical beliefs about the meaning and value of life" (McCarthy, 1996, p. 341). Corporations sometimes face the difficult situation that civil society activists are ready for discourse, but not for shared solutions. In value-based conflicts, discourse may not solve the tension between contradictory demands. In the extreme case, communication might even fuel the conflict. The same effect might arise from situations in which transnational corporations are confronted with contradictory moral demands from different cultures. A discursive ap- proach to organizational legitimacy will have to deal with the growing importance of dissensual communication in pluralizing and globalizing societies (see, e.g., Steinmann and Scherer, 1998).

\section{Media effects}

The mass media play a crucial role as information gatekeepers. They sometimes pull public discourses into certain directions. The confrontation between Shell and Greenpeace in the Brent Spar case illustrates how mass media support of the Greenpeace position emotionalized and manipulated the discourse. However, the manipulative and gatekeeping power of TV channels and newspapers might be compensated by the Internet with its democratizing effect. It does not only deliver additional sources of information, it also plays a key role in the formation of civil society associations and their campaign strategies. Therefore, the role of the mass media and the Internet in a deliberative theory of organizational legitimacy has to be conceptualized in more detail.

Our paper aims at proposing a political fundament for the discussion on corporate legitimacy. The need for a political and communicative re-conceptualization of organizational legitimacy derives from the erosion of its implicit link to the overarching societal context. The cognitive focus of normative compliance is devaluated by the ongoing process of denationalization. While the mainstream debate on CSR regards the corporation as more or less depoliticized, we show how it becomes strongly politicized in the postnational governance dynamic. However, with the dominating neoclassical rhetoric of management theory it seems difficult to cope with the changing normative context and to advocate CSRs beyond economic performance and legal compliance with the same rigor (Scherer et al., forthcoming).

Our proposal to shift the attention from cognitive and pragmatic to moral legitimacy is not contradictory to Suchman's (1995) view on organizational legitimacy. The idea of moral legitimacy as a discursive concept is already part of his conceptualization, but Suchman does not go beyond the mere formulation of the idea. We contribute to the debate by connecting organizational legitimacy to a deliberative approach of political theory thus elaborating on the idea of a communicatively constructed 
corporate legitimacy. We place the idea of corporate acceptance into the communicative network of public communication. The politicization of the corporation seems to be the unavoidable consequence of the emerging democratic governance in a world society without a world state. Theories of CSR will have to operate under a postnational constellation.

\section{Notes}

1 We use "CSR research" as an umbrella term for the notions further mentioned in the text.

2 Whether one principle should be priviledged over the other is a matter of debate in political philosophy. Liberal authors point to the natural rights with which any individual is born, while republican or communitarian inspired authors suggest that any right and its meaning ultimately originates in processes of social interaction and construction (see, e.g., Habermas, 1998a, on the internal relation between the rule of law and democracy).

3 It is not necessary here to further touch upon the principal-agency issue as it is the aim of principal agency theory to explain the conditions under which managers behave as if they were entrepreneurs, i.e. the owners of the firm.

\section{References}

Ashforth, B. E. and B. W. Gibbs: 1990, 'The Doubleedge of Organizational Legitimation', Organization Science 1, 177-194.

Beck, U.: 1992, Risk Society Towards a New Modernity (Sage, Thousand Oaks, CA).

Beck, U.: 2000, What is Globalization? (Polity Press, Cambridge, UK)

Beck-Gernsheim, E. and U. Beck: 2002, Individualization: Institutionalized Individualism and its Social and Political Consequences (Sage, London).

Benhabib, S.: 1993, Situating the Self: Gender, Community, and Postmodernism in Contemporary Ethics (Routledge, New York)

Berger, B. L. and T. Luckmann: 1966, The Social Construction of Reality: A Treatise on the Sociology of Knowledge (Anchor, New York).

Berle, A. A. and G. C. Means: 1932, The Modern Corporation and Private Property (Macmillan, New York).
Block, F.: 1994, 'The Roles of the State in the Economy', in N. J. Smelser and R. Swedberg (eds), The Handbook of Economic Sociology (Princeton University Press, Princeton, N.J.), pp. 691-710.

Bohman, J.: 1998, 'The Coming Age of Deliberative Democracy', Journal of Political Philosophy 6(4), 400-425.

Boli, J. and G. M. Thomas (Eds): 1999, Constructing World Culture: International Nongovernmental Organizations since 1875 (Stanford University Press, Stanford, Calif).

Calton, J. M. and N. B. Kurland: 1996, 'A Theory of Stakeholder Enabling: Giving Voice to an Emerging Postmodern Praxis of Organizational Discourse', in D. M. Boje, R. P. Gephart and T. J. Thatchenkery (eds), Postmodern Management and Organization Theory (Sage, Thousand Oaks, CA), pp. 154-180.

Calton, J. M. and S. L. Payne: 2003, 'Coping With Paradox', Business and Society 42(1), 7-42.

Carroll, A. B.: 1979, 'A Three-Dimensional Conceptual Model of Corporate Performance', Academy of Management Review 4, 497-505.

Carroll, A. B.: 1998, 'The Four Faces of Corporate Citizenship', Business and Society Review 100(1), 1-7.

Cohen, J.: 1989, 'Deliberation and Democratic Legitimacy', in A. Hamlin and P. Pettit (eds), The Good Polity: Normative Analysis of the State (Basil Blackwell, Oxford), pp. 17-34.

Dahl, R. A.: 1967, Democracy in the United States (Rand McNally and Co, Chicago).

Deetz, S.: 1995, Transforming Communication, Transforming Business: Building Responsive and Responsible Workplaces (Hampton Press, Cresskill, NJ.).

DiMaggio, P. J. and W. W. Powell: 1983, 'The Iron Cage Revisited: Institutional Isomorphism and Collective Rationality in Organizational Fields', American Sociological Review 48, 147-160.

Doh, J. P. and H. Teegen: 2004, Globalization and NGOs. Transforming Business, Governments, and Society (Praeger, Westport, Conn.).

Donaldson, T. and L. Preston: 1995, 'The Stakeholder Theory of the Corporation: Concepts, Evidence, and Implications', Academy of Management Review 20, 65-91.

Donaldson, T. and T. Dunfee: 1999, Ties That Bind: A Social Contract Approach to Business Ethics (Harvard Business School Press, Boston).

Dowling, J. and J. Pfeffer: 1975, 'Organizational Legitimacy: Social Values and Organizational Behaviour', Pacific Sociological Review 18, 122-136.

Dryzek, J. S.: 1999, 'Transnational Democracy', Journal of Political Philosophy 7(1), 30-51.

Dryzek, J. S.: 2001, 'Legitimacy and Economy in Deliberative Democracy', Political Theory 29, 651-669. 
Dubbink, W.: 2004, 'The Fragile Structure of Freemarket Society', Business Ethics Quarterly 14(1), 23-46.

Easton, D.: 1969, A Systems Analysis of Political Life (University of Chicago Press, Chicago)

Economist: 2005, 'The Good Company', Economist Jan. 22, 2005, pp. 3-18.

Elster, J.: 1986, 'The Market and the Forum: Three Varieties of Political Theory', in J. Elster and A. Hylland (eds), Foundations of Social Choice Theory (Cambridge University Press, Cambridge), pp. 103132.

Epstein, E. M.: 1972, 'The Historical Enigma of Corporate Legitimacy', California Law Review 60, 17011718.

Epstein, E. M. and D. Votaw (Eds): 1978, Rationality, Legitimacy, and Responsibility (Goodyear Publishing, Santa Monica).

Fombrun, C. J.: 2001, 'Corporate Reputations as Economic Assets', in M. A. Hitt, R. E. Freeman and J. S. Harrison (eds), The Blackwell Handbook of Strategic Management (Blackwell, Oxford), pp. 289-312.

Freeman, R. E.: 2002, 'A Stakeholder Theory of the Modern Corporation', in L. P. Hartman (eds), Perspectives in Business Ethics (McGraw-Hill, Boston), pp. 171-181.

Friedman, M.: 1962, Capitalism and Freedom (University of Chicago Press, Chicago)

Friedman, M.: 1970, 'The Social Responsibility of Business is to Increase its Profit', in The New York Times Magazine, 13 September. Reprinted in T. Donaldson and P. H. Werhane (eds): 1988, Ethical Issues in Business. A Philosophical Approach (Prentice Hall, Englewood Cliffs), pp. 217-223.

Fung, A.: 2005, 'Deliberation Before the Revolution', Political Theory 33, 397-419.

Gutman, A. and F. Thompson: 1996, Democracy and Disagreement (Belknap Press, Cambridge, Mass).

Habermas, J.: 1990, 'Discourse Ethics: Notes on a Program of Philosophical Justification', in J. Habermas (eds), Moral Consciousness and Communicative Action (MIT-Press, Cambridge, Mass), pp. 43-115.

Habermas, J.: 1993, 'Remarks on Discourse Ethics', in J. Habermas (eds), Justification and Application: Remarks on Discourse Ethics (MIT Press, Cambridge, Mass), pp. 19-111.

Habermas, J.: 1996, Between Facts and Norms (MIT Press, Cambridge, Mass)

Habermas, J.: 1998a, 'On the Internal Relation between the Rule of Law and Democracy', in J. Habermas (eds), The Inclusion of the Other. Studies in Political Theory (MIT Press, Cambridge, Mass), pp. 253-264.

Habermas, J.: 1998b, 'Three Normative Models of Democracy', in J. Habermas (eds), The Inclusion of the
Other (Studies in Political Theory. MIT Press, Cambridge, Mass), pp. 239-252.

Habermas, J.: 2001, The Postnational Constellation (MIT Press, Cambridge, Mass)

Hannan, M. T. and G. R. Carroll: 1992, Dynamics of Organizational Populations: Density, Legitimation and Competition (Oxford University Press, Oxford).

Harman, W. and M. Porter (Eds): 1997, The New Business of Business: Sharing Responsibility for a Positive Global Future (Berrett-Koehler, San Francisco).

Hayek, F. V.: 1960, The Constitution of Liberty (Routledge \& Kegan Paul, London)

Henderson, P. D.: 2001, Misguided Virtue False Notions of Corporate Social Responsibility (Institute of Economic Affairs, London).

Hertz, N.: 2001, 'Better to Shop Than to Vote?', Business Ethics: A European Review 10, 190-193.

Hill, C. W. L. and T. M. Jones: 1992, 'StakeholderAgency Theory', Journal of Management Studies 29(2), 131-154.

Hillman, A. J., G. Keim and D. Schuler: 2004, 'Corporate Political Activity: A Review and Research Agenda', Journal of Management 30, 837-857.

Huntington, S. P.: 1998, Clash of Civilizations and the Remaking of World Order (Simon \& Schuster, New York)

Hurst, J. W.: 1970, The Legitimacy of the Business Corporation in the Law of the United States, 1780-1970 (University Press of Virginia, Charlottesville)

Jensen, M. C.: 2002, 'Value Maximization, Stakeholder Theory, and the Corporate Objective Function', Business Ethics Quarterly 12, 235-256.

Johnson, J. and M. J. Holub: 2003, 'Questioning Organizational Legitimacy: The Case of U.S. Expatriates', Journal of Business Ethics 47, 269-293.

Jones, T. M.: 1995, 'Instrumental Stakeholder Theory: A Synthesis of Ethics and Economics', Academy of Management Review 20, 404-437.

Keck, M. E. and K. Sikkink: 1998, Activists Beyond Borders: Advocacy Networks in International Politics (Cornell University Press, New York).

Keim, G. D.: 2001, 'Business and Public Policy. Competing in the Political Market Place', in M. Hitt, R. Freeman and J. Harrison (eds), The Blackwell Handbook of Strategic Management (Blackwell, Oxford), pp. 583-601.

Klein, N.: 2000, No Logo (Picador, New York)

Kobrin, S. J.: 2001, 'Sovereignity@bay: Globalization, Multinational Enterprise, and the International Political System', in A. M. Rugman and T. L. Brewer (eds), The Oxford Handbook of International Business (Oxford University Press, New York), pp. 181-205. 
Kostova, T. and S. Zaheer: 1999, 'Organizational Legitimacy under Conditions of Complexity: The Case of the Multinational Enterprise', Academy of Management Review 24(1), 64-81.

Kuhn, T. and K. L. Ashcraft: 2003, 'Corporate Scandal and the Theory of the Firm. Formulation the Contributions of Organizational Communication Studies', Management Communication Quarterly 17, 20-57.

Lal, D.: 2003, 'Private Morality and Capitalism: Learning from the Past', in J. Dunning. (ed.), Making Globalization Good (Oxford University Press, Oxford), pp. 41-60.

Levitt, T.: 1970, 'The Dangers of Social Responsibility', in T. Meloan, S. Smith and J. Wheatly (eds), Managerial Marketing Policies and Decisions (Houghton Mifflin, Boston), pp. 461-475.

MacPherson, C. B.: 1962, The Political Theory of Possessive Individualism Hobbes to Locke (Oxford University Press, Oxford).

Maignan, I. and O. C. Ferrell: 2000, 'Measuring Corporate Citizenship in Two Countries: The Case of the United States and France', Journal of Business Ethics 23, 283-297.

Manin, B.: 1987, 'On Legitimacy and Political Deliberation', Political Theory 15(3), 338-368.

Maragia, B.: 2002, 'Almost There: Another Way of Conceptualizing and Explaining NGOs' Quest for Legitimacy in Global Politics', Non-State Actors and International Law 2, 301-332.

Margolis, J. D. and J. P. Walsh: 2003, 'Misery Loves Companies: Rethinking Social Initiatives by Business', Administrative Science Quarterly 48, 268-305.

Marshall, T. H.: 1965, Class, Citizenship and Social Development (Anchor Books, New York)

Matten, D. and A. Crane: 2005, 'Corporate Citizenship: Towards an Extended Theoretical Conceptualization', Academy of Management Review 30, 166-179.

Maurer, J. G.: 1971, Readings in Organizational Theory: Open System Approaches (Random House, New York)

McCarthy, T.: 1996, 'Legitimacy and Diversity: Dialectical Reflections on Analytical Distinctions', Rechtstheorie 27, 329-365.

McWilliams, A. and D. Siegel: 2001, 'Corporate Social Responsibility: A Theory of the Firm Perspective', Academy of Management Review 26, 117-127.

Meyer, J. and R. Scott: 1983, 'Centralization and the Legitimacy Problems of Local Government', in J. Meyer and R. Scott (eds), Organizational Environment: Rituals and Rationality (Sage, Newbury Park), pp. 199-216.

Meyer, J. W. and B. Rowan: 1977, 'Institutionalized Organizations: Formal Structure as Myth and Ceremony', American Journal of Sociology 83, 340-63.
Mitchel, N.: 1986, 'Corporate Power, Legitimacy, and Social Policy', The Western Political Quarterly 39(2), 197-212.

Nanz, P. and J. Steffek: 2004, 'Global Governance, Participation and the Public Sphere', Government and Opposition 39(2), 314-335.

Neilsen, E. H. and M. V. Hayagreeva Rao: 1987, 'The Strategy-Legitimacy Nexus: A Thick Description', Academy of Management Review 12, 523-533.

Noonan, J.: 2005, 'Modernization, Rights, and Democratic Society: The Limits of Habermas's Democratic Theory', Res Publica 11, 101-123.

Oliver, C.: 1991, 'Strategic Responses to Institutional Processes', Academy of Management Review 16, 145170.

Oliver, C.: 1996, 'The Institutional Embeddedness of Economic Activity', Advances in Strategic Management 13, 163-186.

Orlitzky, M., F. L. Schmidt and S. L. Rynes: 2003, 'Corporate Social and Financial Performance: A Metaanalysis', Organization Studies 24, 403-441.

Oosterhout, J. V.: 2005, 'Dialogue', Corporate Citizenship: An Idea Whose Time Has Not Yet Come. Academy of Management Review 30, 677-681.

Palan, R.: 2003, The Offshore World Sovereign Markets, Virtual Places, and Nomad Millionaires (Cornell University Press, Ithaca).

Parsons, T.: 1960, Structure and Process in Modern Society (Free Press, Glencoe, Ill)

Peters, F.: 2004, 'Choice, Consent, and the Legitimacy of Market Transactions', Economics and Philosophy 20, 118.

Perrow, C.: 2000, 'An Organizational Analysis of Organizational Theory', Contemporary Sociology 29, 469476.

Pfeffer, J. and G. Salancik: 1978, The External Control of Organizations: A Resource Dependence Perspective (Harper \& Row, New York).

Reich, R.: 1998, 'The New Meaning of Corporate Social Responsibility', California Management Review 40(2), 8-17.

Rondinelli, D. A.: 2002, 'Transnational Corporations: International Citizens or New Sovereigns?', Business and Society Review 107(4), 391-413.

Rowley, T. J. and M. Moldoveanu: 2003, 'When Will Stakeholder Groups Act? An Interest- and Identitybased Model of Stakeholder Group Mobilization', Academy of Management Review 28, 204-219.

Scherer, A. G.: 2003, Multinationale Unternehmen und Globalisierung (Physica, Heidelberg)

Scherer, A. G. and G. Palazzo, 'Towards a Political Conception of Corporate Responsibility. Business and 
Society Seen from A Habermasian Perspective', Academy of Management Review (Forthcoming).

Scherer, A. G., G. Palazzo and D. Baumann: 'Global Rules and Private Actors. Towards a New Role of the TNC in the Global Governance', Business Ethics Quarterly (Forthcoming).

Scherer, A. G. and M. Smid: 2000, 'The Downward Spiral and the U.S. Model Business Principles. Why MNEs Should Take Responsibility for the Improvement of World-wide Social and Environmental Conditions', Management International Review 40, 351-371.

Sethi, S. P.: 1975, 'Dimensions of Corporate Social Performance: An Analytical Framework', California Management Review 17(3), 58-64.

Sethi, S. P.: 2002, 'Standards for Corporate Conduct in the International Arena: Challenges and Opportunities for Multinational Corporations', Business and Society Review 107, 20-40.

Shell, G. R.: 2004, Make the Rules or your Rivals Will (Crown Business, New York)

Skinner, Q.: 1989, 'The State', in T. Ball, J. Farr and R. L. Hanson (eds), Political Innovation and Conceptual Change (Cambridge University Press, Cambridge, UK), pp. 90-131.

Smith, J., C. Chatfield and R. Pagnucco: 1997, Transnational Social Movements and Global Politics: Solidarity Beyond the State (Syracuse University Press, Syracuse, NY).

Spar, D. L. and L. T. La Mure: 2003, 'The Power of Activism: Assessing the Impact of NGOs on Global Business', California Management Review 45, 78-101.

Steffek, J.: 2003, 'The Legitimation of International Governance: A Discourse Approach', European Journal of International Relations 9(2), 249-275.

Steinmann, H. and A. G. Scherer: 1998, 'Corporate Ethics and Global Business. Philosophical Considerations on Intercultural Management', in B. N. Kumar and H. Steinmann (eds), Ethics in International Business (De Gruyter, New York), pp. 13-46.

Steinmann, H. and A. G. Scherer: 2000, 'Corporate Ethics and Management Theory', in P. Koslowski. (ed.), Contemporary Economic Ethics and Business Ethics (Springer, Berlin), pp. 148-192.

Strand, R.: 1983, 'A Systems Paradigm of Organizational Adaptations to the Social Environment', Academy of Management Review 8, 90-96.

Suchman, M. C.: 1995, 'Managing Legitimacy: Strategic and Institutional Approaches', Academy of Management Review 20, 571-610.

Sundaram, A. K. and A. C. Inkpen: 2004, 'The Corporate Objective Revisited', Organization Science 15, 350-363.

Suddaby, R. and R. Greenwood: 2005, 'Rhetorical Strategies of Legitimacy', Administrative Science Quarterly 50, 35-67.
Swanson, D. L.: 1999, 'Towards an Integrative Theory of Business and Society: A Research Strategy for Corporate Social Performance', Academy of Management Review 24, 506-521.

Tapscott, D. and D. Ticoll: 2003, The Naked Corporation (Free Press, New York).

Ulrich, P.: 1993, Transformation der ökonomischen Vernunft (Haupt, Bern)

Ulrich, P.: 2002, 'Ethics and Economics', in L. Zsolnai. (ed.), Ethics in the Economy (Peter Lang, Oxford).

Vogel, D. J.: 2005, 'Is there a Market for Virtue? The Business Case for Corporate Social Responsibility', California Management Review 47(Summer 2005), 19-45.

Waddock, S.: 2000, 'The Multiple Bottom Lines of Corporate Citizenship: Social Investing, Reputation, and Responsibility Audits', Business and Society Review 105(3), 323-345.

Walsh, J. P., K. Weber and J. D. Margolis: 2003, 'Social Issues and Management: Our Lost Cause Found', Journal of Management 29, 859-881.

Wartick, S. L. and P. L. Cochran: 1985, 'The Evolution of the Corporate Social Performance Model', Academy of Management Review 10, 758-769.

Weber, M.: 1922/1978, Economy and Society (University of California Press, Berkeley)

Wicks, A. and R. E. Freeman: 1998, 'Organization Studies and the New Pragmatism: Positivism, AntiPositivism, and the Search for Ethics', Organization Science 9, 123-149.

Wolf, K. D.: 2005, 'Private Actors and the Legitimacy of Governance Beyond the State. Conceptional Outlines and Empirical Explorations, in A. Benz and I. Papadopoulos (eds), Governance and Democratic Legitimacy: Transnational, European, and Multi-Level-Issues (Routledge, London), pp. 200-227.

Wood, D. J.: 1991, 'Corporate Social Performance Revisited', Academy of Management Review 16, 691718.

Wulfson, M.: 2001, 'The Ethics of Corporate Social Responsibility and Philanthropic Ventures', Journal of Business Ethics 29, 135-145.

Young, I. M.: 2001, 'Activist Challenges to Deliberative Democracy', Political Theory 29, 670-690.

Young, I. M.: 2003, 'From Guilt to Solidarity. Sweatshops and Political Responsibility', Dissent 50(2), 39-44.

Young, I. M.: 2004, 'Responsibility and Global Labor Justice', The Journal of Political Philosophy 12, 365-388.

Zadek, S.: 2004, 'The Path to Corporate Responsibility', Harvard Business Review 82(December), 125-132.

Zald, M. N., C. Morrill and H. Rao: 2005, 'The Impact of Social Movements on Organizations', in G. F. Davis, D. McAdam, W. R. Scott and M. N. Zald (eds), Social 
Movements and Organizations Theory (Cambridge University Press, Cambridge, UK), pp. 253-279.

Zürn, M.: 2000, 'Democratic Governance Beyond the Nation-State: The EU and Other International Institutions', European Journal of International Relations 6(2), 183-221.

Guido Palazzo

Ecole des Hautes Etudes Commerciales (HEC)

University of Lausanne 619-BFSH-1, CH-1015, Lausanne-Dorigny,

Switzerland

E-mail: guido.palazzo@unil.ch
Andreas Georg Scherer

University of Zurich

Winterthurerstr. 92,

CH-8006, Zurich,

Switzerland

E-mail: andreas.scherer@iou.unizh.ch 